\title{
The Interventions for Sleep Disorders in Children with Attention Deficit and Hyperactivity Disorder: A Narrative Review
}

\author{
Risma Dwi Nur Pratiwi ${ }^{1}$, Siti Yuyun Rahayu Fitri ${ }^{2 *}$ D, Adelse Prima Mulya $^{3}$ D \\ ${ }^{1}$ Undergraduate Student, Faculty of Nursing, Universitas Padjadjaran, Bandung, Indonesia; ${ }^{2}$ Department of Pediatric Nursing, \\ Faculty of Nursing, Universitas Padjadjaran, Bandung, Indonesia; ${ }^{3}$ Department of Community Nursing, Faculty of Nursing, \\ Universitas Padjadjaran, Bandung, Indonesia
}

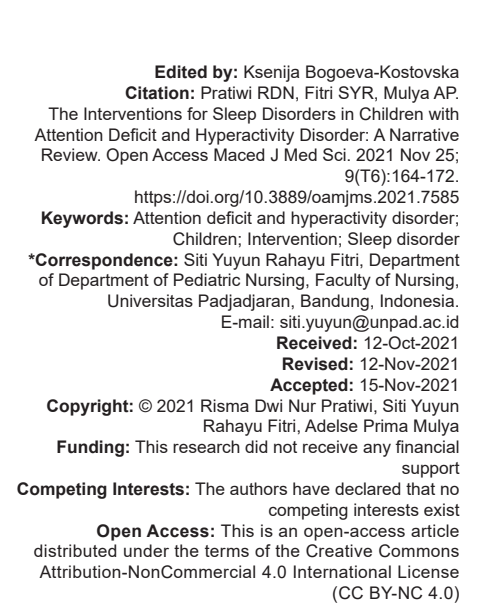

Abstract

BACKGROUND: Attention deficit and hyperactivity disorder (ADHD) is the most common neurodevelopmental disorder in childhood. Children with ADHD have more frequent comorbid sleep disorders than healthy children. The current methods of treating sleep disorders in ADHD children are still focused on pharmacological interventions which in fact only provide little benefit

AIM: This study aims to identify existing studies regarding the types of nonpharmacological and complementary interventions for sleep disorders in children with ADHD using a narrative review approach.

METHODS: This was a narrative review. Inclusion criteria included articles in English and Bahasa, full-text articles, primary studies, and children with ADHD aged 18 years with or without comorbidities as the research sample, and the article having been published in the last 10 years. Searches were performed in several databases: PubMed Springer, Web of Science, and Google Scholar.

RESULTS: The result showed that programs for managing sleep disorder in ADHD are behavioral therapy, behaviora parent training (BPT), behavioral sleep intervention, neurofeedback, mind-body therapy, L-theanine supplementation, horse milk supplementation, and play therapy. The programs are found to be effective in improving sleep.

CONCLUSION: The program most comprehensive with a high level of ease of implementation was BPT.

\section{Introduction}

The period of growth and development of children is prone to disturbances and deviations. One of the child developmental disorders that focus on neurodevelopment is Attention Deficit and Hyperactivity Disorder (ADHD). The global prevalence of ADHD was estimated at $7.2 \%$ in 2015 for children aged $<18$ years [1], and the prevalence of ADHD that continues into adulthood is $4 \%$ [2]. In Indonesia, it was reported that $26.2 \%$ of children aged 6-12 years were suspected of having ADHD and until now the number continues to increase [3].

Previous research has stated that ADHD is the result of inadequate production of norepinephrine and dopamine in the Prefrontal Cortex (PFC) which causes children to become forgetful, easily distracted, impulsive, and experience deviant social behavior [4]. ADHD is classified into three types based on symptoms, namely: ADHD-I with symptoms that appear in the form of inattention, ADHD-H with symptoms that appear in the form of hyperactive and impulsive behavior, and ADHD-C with combined symptoms of ADHD-I and ADHD-H [5], [6].
Children with ADHD not only experience difficulties from the symptoms they experience, but they are also often accompanied by various comorbidities. Psychiatric comorbidities and other neurodevelopmental disorders are common in children with ADHD [7]. Nikles et al. (2020) found that comorbid sleep disorders were the most frequent comorbidities affecting children with ADHD in up to $50-70 \%$ of the total sufferers. Several comorbidities can be related to each other. For example, in research from Virring et al. (2016) who examined the effect of psychiatric comorbid symptoms on sleep in children with ADHD, the results showed that psychiatric comorbidities were considered to cause comorbid sleep disorders. This is supported by Jan et al. (2011), who stated that several ADHD comorbidities can trigger sleep disorders, namely autism spectrum disorder (ASD), internalization disorders, and externalization disorders [6], [8]. These three conditions are the conditions most often associated with sleep disorders in children with ADHD.

Inadequate sleep will have various impacts on children, especially those with ADHD. At the neurobiological level, the impact of sleep disorders is to increase activity in brain networks related to emotions so that it can lead to increased emotional lability [9]. Sleep 
deprivation is associated with impaired communication between the emotional and emotional areas, known as PFC [9]. PFC is involved in several cognitive processes so that sleep deprivation will indirectly interfere with the cognitive function of children with ADHD [5]. In addition, sleep disturbances can cause a progressive worsening of the executive function of children with ADHD [10].

A previous research has shown that the relationship between sleep problems and ADHD is a two-way relationship. Sleep disorders can both cause and worsen symptoms of inattention and hyperactivity/ impulsivity, and medications used to treat symptoms can both cause and worsen certain sleep disorders [11]. Persistent sleep loss can both cause and worsen cognitive impairment [5] and behavior [10]. As stated by Reynolds et al. (2017), sleep problems in children are not only related to academic disorders, functional behavior, emotions, and neuropsychological abilities but can affect family unity.

Research on the treatment of sleep disorders in children with ADHD is quite developed, but it needs to be explored even further. The results of a systematic review states that the treatment of ADHD symptoms and sleep disorders in children includes the application of good sleep hygiene, giving melatonin to increase sleep-wake rhythms so that children tend to wake up earlier, and giving higher doses of stimulants to reduce insomnia secondarily [12]. In one research stated that the administration of methylphenidate can improve sleep efficiency including the quality, composition, continuity, and consolidation of sleep, which improved after 1 week of administration [13]. However, methylphenidate administration only had a secondary effect on sleep problems as previously cited by Vigliano et al. (2016). The detrimental effect of stimulants is the worsening of sleep disturbances and in the long-term use can increase the risk of growth delay [14]. Another problem arises when parents realize that medication has side effects, which can worsen the child's condition because parents will tend to disobey the medication regimen.

To complement the shortcomings of pharmacological therapy, non-pharmacological and complementary approaches can be the right choice. Non-pharmacological therapies have been studied and proven to produce excellent improvement and long-term effects in the sleep patterns of patients with insomnia [15]. In addition, complementary and integrative approaches have been used to treat or manage disorders and symptoms related to the nervous system [16]. An analysis result based on a report submitted by Phillips (2014) stated that only $12 \%$ of children with ADHD were using complementary and alternative therapies to treat ADHD [17]. This shows that there is great potential for the development of the application of complementary therapies in Indonesia. This study was conducted to answer existing problems, namely: "what kind of intervention, non-pharmacological and complementary, can be given to treat sleep disorders in children with ADHD?"

\section{Methods}

The study aims to summarize and broadly evaluate the previous findings regarding the management of sleep disorders in children with ADHD. A search was performed in several databases: PubMed, Springer, Web of Science, and Google Scholar. Inclusion criteria included articles using English and Indonesian, full-text articles, primary studies, and children with ADHD aged 18 years with or without comorbidities as the research sample, and publication of the article over the past 10 years (20112021). After collecting the search results articles from various databases, the authors assess the duplication of articles by screening titles and abstracts. If similar articles are found, the authors eliminate duplicate articles. Articles that pass the title, abstract, and content selection thoroughly are read by the author in their entirety to obtain articles suitable for use to answer specific study objectives (Figure 1).

The selected article is then read in-depth by the author for subsequent analysis. At this stage, the author takes information that is relevant to the discussion. This type of information can be labeled study notes, which include a summary of the study, followed by detailed information about the methods, results, and interpretation of the results [18].

The information obtained from the studies can be processed in two ways: separately or synthetically [18]. In a separate organizational technique, the details of each study (including a study summary of the methods, results, and interpretation of the results) are recorded in a table. All data extraction results were then analyzed in the form of a narrative that explained the findings in groups for treating sleep disorders in children with ADHD (Table 1).

\section{Results}

The results of the search for articles from the database in the form of PubMed, Springer, Web of Science, and the search engine Google Scholar using the relevant keywords obtained as many as 24,498 articles. After eliminating the duplication of articles, the number of articles reduced to 1370 . The article selection stage continued to the title and abstract selection stage with a total of 81 articles obtained. The last stage of article selection is the stage of determining 


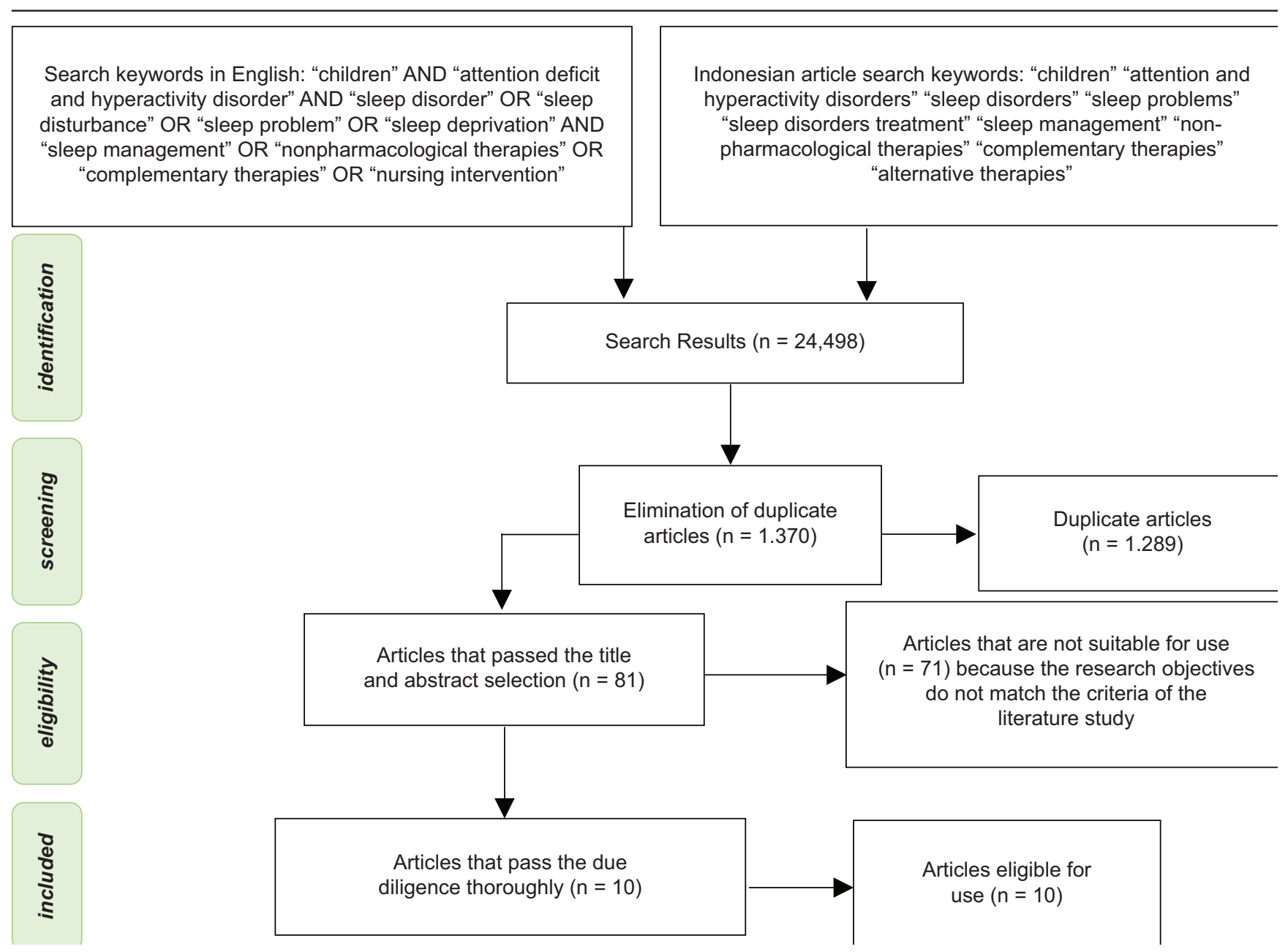

Figure 1: Article search process

\section{Table 1: Data extraction}

\begin{tabular}{|c|c|c|c|c|c|c|}
\hline $\begin{array}{l}\text { Author, Year of } \\
\text { Publication, and Place } \\
\text { of Research }\end{array}$ & Objectives and Outcomes & Methods and Participants & Child Age & Instrument & Program & Results \\
\hline $\begin{array}{l}\text { Sciberras et al. }{ }^{[19]} \\
\text { Melbourne, Australia }\end{array}$ & $\begin{array}{l}\text { Evaluate the feasibility and } \\
\text { usefulness of behavioral } \\
\text { sleep programs for children } \\
\text { with ADHD and explore the } \\
\text { impact of different program } \\
\text { doses on child and family } \\
\text { outcomes. Primary outcomes: } \\
\text { sleep disturbance, ADHD } \\
\text { symptom severity, QoL, daily } \\
\text { functioning, school attendance. } \\
\text { Secondary (caregiver) } \\
\text { outcomes: mental health } \\
\text { attendance at work }\end{array}$ & $\begin{array}{l}\text { Randomized controlled } \\
\text { trial } \\
27 \text { families with ADHD } \\
\text { children }\end{array}$ & $5-14$ years & $\begin{array}{l}\text { CSHQ, ADHD-RS IV, } \\
\text { PQoL 4.0, DPREMB, } \\
\text { DASS }\end{array}$ & Behavioral therapy & $\begin{array}{l}\text { The intervention administered to } \\
\text { the extended intervention group } \\
\text { resulted in decreased sleep } \\
\text { problems, minimal changes in } \\
\text { ADHD symptom scores, improved } \\
\text { children's quality of life and daily } \\
\text { functioning, and decreased } \\
\text { parental anxiety }\end{array}$ \\
\hline $\begin{array}{l}\text { Sciberras et al. [23]. } \\
\text { Victoria, Australia }\end{array}$ & $\begin{array}{l}\text { Determine whether BSIs for } \\
\text { children with ADHD lead to } \\
\text { lasting benefits, and examine } \\
\text { factors associated with } \\
\text { treatment response. Outcomes: } \\
\text { sleep, PQoL, behavior, daily } \\
\text { functioning, comorbidities, } \\
\text { mental health of the elderly }\end{array}$ & $\begin{array}{l}\text { Randomized controlled } \\
\text { trial } \\
183 \text { ADHD children }\end{array}$ & $5-13$ years & $\begin{array}{l}\text { CSHQ, PedsQoL, } \\
\text { SDQ, DPREMB, DASS, } \\
\text { ADISC-IV }\end{array}$ & $\mathrm{BSI}$ & $\begin{array}{l}\text { The intervention resulted in } \\
\text { decreased sleep onset delay, } \\
\text { night awakening, ADHD symptom } \\
\text { severity, difficulty with daily } \\
\text { functioning, negative behavior, } \\
\text { minimal reduction in sleep refusal } \\
\text { behavior, sleep duration, sleep } \\
\text { anxiety, parasomnias, and daytime } \\
\text { sleepiness, and improved quality of } \\
\text { life and mental health of parents }\end{array}$ \\
\hline $\begin{array}{l}\text { Rigney et al. [24]. } \\
\text { Canada }\end{array}$ & $\begin{array}{l}\text { Knowing the similarities, the } \\
\text { trend of outcomes used, and } \\
\text { the quality of the methodology } \\
\text { in providing BSI for children } \\
\text { with a neurodevelopmental } \\
\text { disorder (NDD), especially } \\
\text { in children with ADHD, ASD, } \\
\text { cerebral palsy, and fetal alcohol } \\
\text { spectrum disorder. Outcomes: } \\
\text { sleep concepts and behaviors, } \\
\text { night awakenings, total sleep } \\
\text { time, sleep onset latency }\end{array}$ & $\begin{array}{l}\text { Systematic Review } \\
435 \text { children }\end{array}$ & $4-15$ years & $\begin{array}{l}\text { Parent's report and } \\
\text { actigraphy }\end{array}$ & BSI & $\begin{array}{l}\text { Improved sleep onset } \\
\text { latency (SOL), sleep duration, and } \\
\text { sleep (in children following the } \\
\text { yoga-only program) and decreased } \\
\text { parental complaints about sleep } \\
\text { disturbances and sleep problems in } \\
\text { any of the outcomes (in the special } \\
\text { modified group) }\end{array}$ \\
\hline
\end{tabular}


Table 1: (Continued)

\begin{tabular}{|c|c|c|c|c|c|c|}
\hline $\begin{array}{l}\text { Author, Year of } \\
\text { Publication, and Place } \\
\text { of Research }\end{array}$ & Objectives and Outcomes & Methods and Participants & Child Age & Instrument & Program & Results \\
\hline $\begin{array}{l}\text { Herbert and } \\
\text { Esparham [25]. United } \\
\text { States of America }\end{array}$ & $\begin{array}{l}\text { Review current research } \\
\text { studying mind-body therapies } \\
\text { for the treatment of children } \\
\text { diagnosed with ADHD. } \\
\text { Outcome: ADHD symptoms, } \\
\text { the severity of the disorder, } \\
\text { behavior, level of attention, } \\
\text { awareness and orientation, } \\
\text { impaired attention, inhibitory } \\
\text { abilities, working memory }\end{array}$ & $\begin{array}{l}\text { Literature review } \\
134 \text { children with ADHD }\end{array}$ & $5-16$ years & $\begin{array}{l}\text { SNAP-IV, CGI-S, BOF, } \\
\text { ADHD-RS IV, ANT, stroop } \\
\text { task, trial marking test, } \\
\text { and digit span }\end{array}$ & $\mathrm{MbT}$ & $\begin{array}{l}\text { Reduced anxiety, daydreaming, } \\
\text { negative emotions, ADHD } \\
\text { symptoms, significantly improving } \\
\text { behavior, increased dopamine } \\
\text { and norepinephrine function, } \\
\text { executive function and cognitive } \\
\text { function, mood, immunity, stress } \\
\text { management. Also reduced anxiety } \\
\text { and pain, medication dosage, and } \\
\text { increased TA for a sleep increase }\end{array}$ \\
\hline $\begin{array}{l}\text { Corkum et al. [20]. } \\
\text { Canada }\end{array}$ & $\begin{array}{l}\text { Determine the effectiveness of } \\
\text { the intervention on sleep and } \\
\text { psychosocial functioning of } \\
\text { children with ADHD. Outcomes: } \\
\text { total sleep disturbances, } \\
\text { brain activity, behavioral } \\
\text { disturbances (impaired } \\
\text { internalization and } \\
\text { externalization), and parental } \\
\text { satisfaction }\end{array}$ & $\begin{array}{l}\text { Randomized Controlled } \\
\text { Trial } \\
26 \text { families with ADHD }\end{array}$ & $5-12$ years & $\begin{array}{l}\text { CSHQ, actigraphy, CBCL, } \\
\text { SRS }\end{array}$ & $\begin{array}{l}\text { Behavioral therapy } \\
\text { long distance }\end{array}$ & $\begin{array}{l}\text { Decreased sleep problems }(41.7 \% \\
\text { score of ADHD children } \\
\text { became non-clinical), improved } \\
\text { psychosocial functioning, and } \\
\text { positively increased sleep onset } \\
\text { delay, bedtime resistance, sleep } \\
\text { duration, as well as high levels of } \\
\text { satisfaction }\end{array}$ \\
\hline Jokar et al. [26]. Iran & $\begin{array}{l}\text { Comparing the effect of } \\
\text { conventionally given horse's } \\
\text { milk with cow's milk on sleep } \\
\text { disturbances in children } \\
\text { with ADHD. Outcomes: } \\
\text { bedtime, sleep behavior, night } \\
\text { awakening, and morning } \\
\text { awakening }\end{array}$ & $\begin{array}{l}\text { Randomized double-blind } \\
\text { clinical trial } \\
30 \text { ADHD children other } \\
\text { than ADHD-I type }\end{array}$ & $6-14$ years & $\mathrm{CSHQ}$ & $\begin{array}{l}\text { Supplementation } \\
\text { of horse milk and } \\
\text { cow's milk }\end{array}$ & $\begin{array}{l}\text { Consumption of horse milk reduced } \\
\text { children's sleep problems on } \\
\text { subscales } 1,3 \text {, and } 4 \text { (increased } \\
\text { sleep time, decreased number of } \\
\text { night awakenings, and increased } \\
\text { morning awakening). The order of } \\
\text { consumption of the two types of } \\
\text { milk had no significant effect on the } \\
\text { results of the analysis }\end{array}$ \\
\hline Mehri et al. [27]. Iran & $\begin{array}{l}\text { To examine the effect of } \\
\text { behavioral parental training } \\
\text { on sleep problems in } \\
\text { children diagnosed with } \\
\text { ADHD. Outcomes: bedtime } \\
\text { resistance, sleep onset delay, } \\
\text { sleep duration, anxiety, night } \\
\text { awakenings, parasomnias, } \\
\text { sleep-disordered breathing, } \\
\text { and daytime sleepiness }\end{array}$ & $\begin{array}{l}\text { Randomized Controlled } \\
\text { Trial } \\
56 \text { ADHD children with } \\
\text { participation from } 23 \\
\text { mothers and } 5 \text { fathers }\end{array}$ & $6-12$ years & CSHQ & BPT (CPM) & $\begin{array}{l}\text { Effectively improved sleep } \\
\text { problems in school-age } \\
\text { children with ADHD receiving } \\
\text { methylphenidate treatment. The } \\
\text { intervention resulted in decreased } \\
\text { sleep problems, bedtime } \\
\text { resistance, and increased sleep } \\
\text { duration }\end{array}$ \\
\hline $\begin{array}{l}\text { Geladé et al. [29]. } \\
\text { Dutch }\end{array}$ & $\begin{array}{l}\text { Assessed the long-term } \\
\text { effects of NFB in children } \\
\text { with ADHD and compared } \\
\text { behavioral and neurocognitive } \\
\text { outcomes with a 6-month } \\
\text { naturalistic follow-up of a RCT } \\
\text { on NFB, methylphenidate, } \\
\text { and physical activity (PA). } \\
\text { Primary outcomes: behavioral } \\
\text { problems, ADHD symptoms, } \\
\text { neurocognitive, inhibitory } \\
\text { control, and short-term } \\
\text { memory. Secondary outcome: } \\
\text { sleep quality }\end{array}$ & $\begin{array}{l}\text { Multicenter three-way } \\
\text { parallel-group, balanced, } \\
\text { and randomized study } \\
92 \text { ADHD children }\end{array}$ & 7-13 years old & $\begin{array}{l}\text { SDQ, SWAN, auditory } \\
\text { oddball task, SST, VSWM, } \\
\text { and SDSC. }\end{array}$ & NFB & $\begin{array}{l}\text { The NFB intervention reduced } \\
\text { ADHD (even after controlling for } \\
\text { medication use) was good for } \\
\text { long-term use for ADHD children } \\
\text { taking stimulants but had no } \\
\text { significant effect on sleep quality } \\
\text { and inhibitory control domains }\end{array}$ \\
\hline $\begin{array}{l}\text { El-Nagger et al. [30]. } \\
\text { Jeddah, Saudi Arabia }\end{array}$ & $\begin{array}{l}\text { Evaluating the effect of } \\
\text { implementing play therapy on } \\
\text { ADHD children. Outcomes: } \\
\text { behavioral problems, ADHD } \\
\text { symptoms, and anxiety } \\
\text { symptoms }\end{array}$ & $\begin{array}{l}\text { Quasi experimental } \\
40 \text { ADHD children } \\
\text { accompanied by parents } \\
\text { and teachers }\end{array}$ & $4-12$ years & $\begin{array}{l}\text { CPRS-HI and CTRS-HI, } \\
\text { CSI- } 4 \text {, VADRS, and } \\
\text { VADTRS }\end{array}$ & Play therapy & $\begin{array}{l}\text { The intervention decreased the } \\
\text { sleep disturbance experienced } \\
\text { and was effective in providing a } \\
\text { positive increase in the domains of } \\
\text { fear, anxiety, crying, and reducing } \\
\text { negative behaviors such as thumb } \\
\text { sucking behavior }\end{array}$ \\
\hline
\end{tabular}

the eligibility of articles, resulting in a total of 10 articles that meet the criteria and are considered suitable for use in this literature study. Articles were selected based on predetermined criteria, namely articles using
English and Bahasa, full-text articles, primary studies, and children with ADHD aged 18 years with or without comorbidities as the research sample, and publication of the article over last 10 years (2012-2021). 
The selected articles are studies with a randomized controlled trial research design of 5 articles, a literature review (including a systematic review) of four articles, and a quasi-experimental article of 1 article. Research respondents in all articles focused on children who had been diagnosed and/or had ADHD symptoms with and or without comorbidities. Subsequently, selected articles were thoroughly reviewed to answer the study questions. The article review rubric can be seen in Table 1.

All articles used are articles in English; the authors did not find articles in Indonesian that met the criteria for article selection and study objectives. From all 10 selected articles, there were 8 different interventions given including behavioral therapy, behavioral parent training (BPT), behavioral sleep intervention (BSI), neurofeedback (NFB), mind-body therapy $(\mathrm{MbT})$ and meditation, macronutrient $L$-theanine supplementation, horse milk supplementation, and play therapy. Characteristics of participants are generally children who consume stimulants for the treatment of ADHD symptoms, accompanied by other comorbidities: ASD, internalizing disorders (anxiety or depression), externalizing disorders (oppositional defiant disorder or behavioral disorders), and other neurological disorders).

\section{Discussion}

\section{Non-pharmacological therapy}

\section{Behavioral therapy}

Behavioral therapy is a behavior-based intervention that aims to change and improve individual behavior to achieve a better degree of health. This intervention program is good for ADHD children who experience symptoms of ADHD severity with moderate to severe sleep disturbance, internalizing and externalizing disturbances without moderate to severe cognitive impairment, and other neurological disorders.

A research by Sciberras et al. (2011) on behavioral therapy intervention is provided with three training sessions and is supported by a printed module as a guide for implementing the intervention. In another research from Corkum et al. (2016), the whole series of therapy was done remotely. The therapy, which was provided over telephone, lasted for 5 weeks with a total of 5 training sessions. In both studies, the intervention targets were parents and showed that the participation and ability of parents in providing interventions to children greatly influenced the smoothness of therapy and the optimization of positive effects on children.

During the implementation of the intervention, parents were provided with various information to maximize implementation to their children, including psychoeducation, sleep hygiene, and basic clinical strategies to manage sleep disorders experienced by children. In line with what is previously stated that psychoeducation is the first and main element of choice in providing treatment for sleep disorders in ADHD children with sleep disorders [21]. Similar to psychoeducation, sleep hygiene is an important element in efforts to treat sleep disorders. Providing information and discussing sleep hygiene can help parents to better understand what behaviors of their children can be changed to set strategies to improve children's sleep. Likewise the analysis of the relationship between family support and the quality of life of ADHD children showed that the higher the value of family support, the higher the quality of life of ADHD children [22]. Melatonin, which is formed at bedtime, helps children fall asleep faster or helps children not to experience disturbances at sleep onset. In implementing the intervention, Corkum et al. (2016) stated that distance therapy carried out by telephone was considered to be able to save costs and time, as well as provide easy access for parents to interventions. Scheduled parent training sessions in face-to-face programs are more at risk of clashing with parental work schedules. Comparative evaluation of therapy given face-to-face with therapy given remotely still cannot conclude its effectiveness against sleep disorders in children with ADHD.

\section{$B S I$}

In research conducted by Sciberras et al. (2019), the intervention is good for ADHD children with severe ADHD symptoms, moderate to severe sleep disturbances, who take medication for ADHD symptoms, and have comorbid internalizing (including anxiety) and externalizing disorders. The strategy used depends on the conditions experienced by the child. Sleep difficulties related to sleep onset were managed by an outdoor camping strategy, and the technique used was adult fading. The technique involves reducing the intensity of checking the parent's presence from the child's bed periodically for 7-10 days and rewarding the child for having the courage to sleep without a parent.

The delayed sleep phase is managed with a bedtime fading strategy, where parents adjust their child's sleep schedule according to their usual bedtime, moving this 15 min earlier each night. Children are not allowed to take a nap and parents set a time to wake up in the morning and make sure the child is exposed to the sun in the morning. Insomnia is managed with progressive muscle relaxation strategies and visual imagery, simple cognitive restructuring, reduced sleep time (sleep hours being late for a while, not staying in bed, and doing relaxation movements if the child doesn't sleep after $20 \mathrm{~min}$ ). In line with research results, Wajszilber et al. (2018) state that CBTi is effective for use in adolescents with ADHD. 
In research conducted by Rigney etal. (2018), the BSI program implemented includes a multi-component program, namely the application of psychoeducation, healthy sleep hygiene, reinforcement (positive and negative), extinction, bedtime fading, chronotherapy, diet therapy, and yoga alone. A special modification is in the form of a token economy, where children can "cash-out" tokens as a sign of compliant behavior. The combination of behavioral strategies that are generally applied to children are reinforcement, extinction, and bedtime fading strategies. The prospects for the success of the combination are increased in research that combines the reinforcement of the desired behavior along with the extinction of a particular behavior [31].

\section{$B P T$}

Behavioral strategies used by Mehri et al. (2020) in their research on BPT are sleep hygiene, nutritional health, control of the child's external environment, and the application of CBT. Researchers discussed together with parents to implement healthy sleep hygiene, discuss eating patterns (especially food elimination), and implement regular eating schedules. Further, there was the elimination some foods such as wheat, corn, dairy, and additives (artificial colors, preservatives, and artificial flavors) that are thought to have a destructive effect on ADHD symptoms. Research on food elimination (oligoantigenic diet) states that in addition to showing sensitivity to foods containing artificial coloring, ADHD children are sensitive to natural non-salicylic foods (such as milk, chocolate, soy, eggs, wheat, corn, and nuts) as well as grapes and tomatoes [32].

\section{Play therapy}

Play therapy is included as one method of behavioral therapy under the name of cognitivebehavioral play therapy (CBPT). CBPT is an approach designed to teach coping skills to children by combining cognitive behavioral therapy with pretend play [33]. This program is good for use in school-age children who have had ADHD for <6 years, do not have siblings diagnosed with $\mathrm{ADHD}$, and have sleep disorders. Purpose of play interventions is to build children's confidence, increase children's ability to stay focused, encourage children to show self-control, and teach children to consider consequences before acting [34]. Play therapy can be given by providing reinforcement (positive and/or negative) to children, reward for positive behavior, and token economy behavioral strategies as modifications to improve behavior.

Parents act as co-therapists or companion therapists, aiming to apply therapy at home on an ongoing basis. In a case-series study, children and their parents participated in the cognitive-behavioral play intervention (CBPI) program for 3 sessions for 20-30 min each session. Each parent received a sleep information session lasting
30 min. Results indicate that CBPI is potentially effective for reducing anxiety and difficulty with sleep problems [33].

\section{$N F B$}

NFB is a non-pharmacological and non-invasive approach that aims to reduce ADHD symptoms [35]. The application of NFB in sleep disorders aims to create a relaxed condition, help individuals to fall asleep more easily, and avoid sleep disorders such as anxiety, nightmares, and fear that cause individuals to be very alert (causing sleep onset disorders). In the research conducted by Gelade et al. (2018), the therapy given is limited theta activity $(4-8 \mathrm{~Hz})$ and increased beta activity $(18-30 \mathrm{~Hz}$ ), or what is known as sensorimotor rhythm (SMR) NFB. SMR is the latest NFB protocol that can be applied, especially in individuals with ADHD [36]. SMR was assessed to increase sleep spindle density which was associated with reduced sleep onset latency, increased total sleep time, and exhibited a circadian rhythm similar to melatonin [37]. Sleep can easily occur during objectively controlled alpha or theta wave NFB training [38].

\section{Complementary therapy}

\section{Horse milk supplementation (mare's milk)}

Research conducted by Jokar et al. (2021) stated that horse milk supplementation provides benefits for children with ADHD, including the domain of children's sleep. This is in line with the previous study stated how horse milk can be used as supportive therapy for several conditions (e.g., increased symptoms of ADHD) caused by substances that increase sensitivity by modifying their content [39].

This is backed by the other previous study stated that omega 3 significantly reduced the total sleep disturbance score in children diagnosed with sleep problems but did not affect the total sleep duration, sleep latency, or sleep efficiency of healthy children [40]. This supplementation program is good for school-age ADHD children who do not have comorbid ASD/mood disorders/personality disorders, do not experience mental retardation, do not experience schizophrenia or psychosis, and have at least one disorder in the 4 $\mathrm{CHSQ}$ domains. The weakness of horse milk therapy is the price of milk as is tends to be more expensive.

\section{$M b T$}

A study from Herbert and Esparham (2017) discusses the function of MbT on sleep which is considered effective in reducing sleep disturbances experienced by children with ADHD. This program is good for children with school-age ADHD and is recommended but not limited to ADHD-I, and for children who experience anxiety, emotional problems, 
or sleep disorders. MbT is a type of training program that focuses on physical and psychological training through exercises that involve concentration, deep breathing, and various directed movements. The types used are yoga, tai chi, physical activity, and meditation. Yoga is a combination of physical practice and mindfulness [41].

In the other study stated that tai chi can reduce symptoms of ADHD (inattention, hyperactivity, and impulsivity), defiant behavior, and dysfunction of executive function [42]. In addition to regulating various cognitive activities, previous research has found an association between sleep disturbances and executive function in children with ADHD. Herbert and Esparham (2017) mentioned that physical activity can be an intervention option. Physical activities that can be done include cardiovascular exercise (especially aerobics) and self-defense suitable for children with ADHD. Sleep and exercise had a substantial positive effect on each other [43]. Further, study analysis revealed that moderate-intensity physical activity was considered more effective in improving sleep quality, which could be beneficial for both children and adults [44].

\section{L-theanine macronutrient supplementation}

L-theanine (gamma-glutamylethylamide) is a complementary therapy that is included in the classification of natural products according to the NCCAM. L-theanine is found abundantly in tea leaves (especially black tea) which have an anti-anxiety (anxiolytic) effect, acting through the induction of alpha brain waves without any additive effects. L-theanine stimulates the production of alpha waves directly to create the effect of deep relaxation and a level of mental alertness as achieved through meditation [45]. The relaxing effect caused by L-theanine does not directly induce sleep but rather prepares the body and mind to enter the sleep phase efficiently [28]. In addition, L-theanine can maintain awareness during the day by not causing excessive sleepiness. The neurotransmitter gamma aminobutyric acid (GABA) is a neurotransmitter that inhibits the release of serotonin and dopamine as previously mentioned, playing a role in the regulation of waking behavior. The previous research results showed a decrease in sleep latency, an increase in sleep duration, and an increase in REM and NREM sleep compared to the control group after the administration of a mixture of GABA/L-theanine $(100 / 20 \mathrm{mg} / \mathrm{kg})$ [46].

\section{Limitations of the study}

The literature study has some limitations, especially in the article search process. Several articles with appropriate titles were forced to be excluded from the study because the articles did not contain full-text or were paid articles. In addition, this literature study does not include studies conducted in Indonesia because the authors found it difficult to obtain research conducted in Indonesia that contained topics, objectives, and participants that met the criteria for this study.

\section{Conclusion}

The total articles analyzed by this author amounted to 10 articles that encompassed 8 different types of intervention programs to treat sleep disorders in children with ADHD. The interventions in question are behavioral therapy, BPT, BSI, NFB, MbT, L-theanine macronutrient supplementation, horse milk supplementation, and play therapy. The program that shows the most comprehensiveness with a high level of ease of implementation was BPT.

\section{References}

1. Nikles J, Mitchell GK, de Miranda Araújo R, Harris T, Heussler HS, Punja S, et al. A systematic review of the effectiveness of sleep hygiene in children with ADHD. Psychol Health Med. 2020;25(4):497-518. http://dx.doi.org/10.1080/135 48506.2020.1732431

PMid:32204604

2. Ayu F, Setiawati Y. Interaksi faktor genetik dan lingkungan pada attention deficit/hyperactivity disorder (ADHD) genetics and environment factors in attention deficit/hyperactivity disorder (ADHD). J Psikiatri Surabaya. 2018;6:1-10. http://dx.doi. org/10.20473/jps.v6i2.19434

3. Hapsari II, Iskandarsyah A, Joefiani P, Siregar JR. Teacher and problem in student with ADHD in Indonesia: A case study. Qual Rep. 2020;25(11):4104-26.

4. Punja S, Zorzela L, Hartling L, Urichuk L, Vohra S. Long-acting versus short-acting methylphenidate for paediatric ADHD: A systematic review and meta-analysis of comparative efficacy. BMJ Open. 2013;3(3):e002312. http://doi.org/10.1136/ bmjopen-2012-002312

PMid:23503579

5. Scarpelli S, Gorgoni M, D'Atri A, Reda F, De Gennaro L. Advances in understanding the relationship between sleep and attention deficit-hyperactivity disorder (ADHD). J Clin Med. 2019;8(10):1737. http://doi.org/10.3390/jcm8101737 PMid:31635095

6. Virring A, Lambek R, Thomsen PH, Møller LR, Jennum PJ. Disturbed sleep in attention-deficit hyperactivity disorder (ADHD) is not a question of psychiatric comorbidity or ADHD presentation. J Sleep Res. 2016;25(3):333-40. http://doi. org/10.1111/jsr.12377

PMid:26762193

7. Bélanger SA, Andrews D, Gray C, Korczak D. ADHD in children and youth: Part 1-Etiology, diagnosis, and comorbidity. Paediatr Child Health. 2018;23(7):447-53.

8. Jan YW, Yang CM, Huang YS. Comorbidity and confounding 
factors in attention-deficit/hyperactivity disorder and sleep disorders in children. Psychol Res Behav Manag. 2011;4:139-50. http://doi.org/10.2147/PRBM.S14055

\section{PMid:22114544}

9. Reynolds KC, Patriquin M, Alfano CA, Loveland KA, Pearson DA. Parent-reported problematic sleep behaviors in children with comorbid autism spectrum disorder and attention-deficit/ hyperactivity disorder. Res Autism Spectr Disord. 2017;39:2032. http://doi.org/10.1016/j.rasd.2017.04.003

PMid:29081833

10. Montgomery P, Wiggs L. Definitions of sleeplessness in children with attention-deficit hyperactivity disorder (ADHD): Implications for mothers' mental state, daytime sleepiness and sleep-related cognitions. Child Care Health Dev. 2015;41(1):139-46. http:// doi.org/10.1111/cch.12165

PMid:24924156

11. Vélez-Galarraga $R$, Guillén-Grima $F$, Crespo-Eguílaz $N$, Sánchez-Carpintero R. Prevalence of sleep disorders and their relationship with core symptoms of inattention and hyperactivity in children with attention-deficit/hyperactivity disorder. Eur $\mathrm{J}$ Paediatr Neurol. 2016;20(6):925-37. http://doi.org/10.1016/j. ejpn.2016.07.004

PMid:27461837

12. Vigliano P, Galloni GB, Bagnasco I, Delia G, Moletto A, Mana M, et al. Sleep in children with attention-deficit/hyperactivity disorder (ADHD) before and after 6-month treatment with methylphenidate: A pilot study. Eur J Pediatr. 2016;175(5):695704. http://doi.org/10.1007/s00431-016-2695-9

PMid:26833051

13. Solleveld MM, Schrantee A, Baek HK, Bottelier MA, Tamminga HG, Bouziane C, et al. Effects of 16 weeks of methylphenidate treatment on actigraph-assessed sleep measures in medication-naive children with ADHD. Front Psychiatry. 2020;11:82. http://doi.org/10.3389/fpsyt.2020.00082 PMid:32184743

14. Kosten TR. The Opioid Epidemic Settlements: Who will Benefit? Psychiatr Times; 2019. p. 1-2.

15. Harsora P, Kessmann J. Nonpharmacologic management of chronic insomnia. Am Fam Physician. 2009;79(2):125-30. PMid:19178064

16. National Center for Complementary and Integrative Health. Neurobiological Effects and Mechanisms; 2021. Available: https://www.nccih.nih.gov/about/neurobiological-effects-andmechanisms. [Last accessed on 2021 Mar 06].

17. Siron $Y$, Mushlihah L, Sari N, Dina AE. Diet anak attention-ddeficit hyperactivity disorder (ADHD). Tantangan Orang Tua. 2020;8:161-9.

18. Li S, Wang H. Traditional literature review and research synthesis. In: The Palgrave Handbook of Applied Linguistics Research Methodology. Berlin: Springer; 2018. p. 123-44.

19. Sciberras E, Fulton M, Efron D, Oberklaid F, Hiscock $H$. Managing sleep problems in school aged children with ADHD: A pilot randomised controlled trial. Sleep Med. 2011;12(9):932-5. https://doi.org/10.1016/j.sleep.2011.02.006

PMid:22005602

20. Corkum $P$, Lingley-Pottie $P$, Davidson $F$, McGrath $P$, Chambers CT, Mullane J, et al. Better nights/better daysdistance intervention for insomnia in school-aged children with/ without ADHD: A randomized controlled trial. J Pediatr Psychol. 2016;41(6):701-13. https://doi.org/10.1093/jpepsy/jsw031 PMid:27189687

21. Wajszilber D, Santiseban JA, Gruber R. Sleep disorders in patients with ADHD: Impact and management challenges. Nat Sci Sleep. 2018;10:453-80. https://doi.org/10.2147/NSS. S163074

\section{PMid:30588139}

22. Mulya AP, Yani DI, Sari CW. Relationship between family anxiety, family support and quality of life of attention defcit hiperactivity disorder (Adhd) children. J Keperawatan Padjadjaran. 2019;7(2):164-72.

23. Sciberras E, Mulraney M, Mensah F, Oberklaid F, Efron D, Hiscock $H$. Sustained impact of a sleep intervention and moderators of treatment outcome for children with ADHD: A randomised controlled trial. Psychol Med. 2019;50(2):210-9. https://doi.org/10.1017/S0033291718004063 PMid:30654852

24. Rigney G, Ali NS, Corkum PV, Brown CA, Constantin E, Godbout R, et al. A systematic review to explore the feasibility of a behavioural sleep intervention for insomnia in children with neurodevelopmental disorders: A transdiagnostic approach. Sleep Med Rev. 2018;41:244-54. https://doi.org/10.1016/j. smrv.2018.03.008

PMid:29764710

25. Herbert A, Esparham A. Mind-body therapy for children with attention-deficit/hyperactivity disorder. Children. 2017;4(5):31. https://doi.org/10.3390/children4050031 PMid:28441363

26. Jokar SZ, Sadeghieh T, Sadeghmanesh R, Shakiba M. Comparison of horse and cow milk on sleep disorders in children with attention deficit hyperactivity disorder: A doubleblind randomized clinical trial study. TMR Non Drug Ther. 2021;4:9.

27. Mehri M, Chehrzad MM, Mardani A, Maleki M, Dianatinasab M, Kousha $\mathrm{M}$, et al. The effect of behavioral parent training on sleep problems of school-age children with ADHD: A parallel randomized controlled trial. Arch Psychiatr Nurs. 2020;34(4):261-7. https://doi.org/10.1016/j.apnu.2020.04.001

28. Rao TP, Ozeki M, Juneja LR. In search of a safe natural sleep aid. J Am Coll Nutr. 2015;34(5):436-47. http://doi.org/10.1080/0 7315724.2014.926153

PMid:25759004

29. Geladé K, Janssen TW, Bink M, Twisk JW, van Mourik R, Maras A, et al. A 6-month follow-up of an RCT on behavioral and neurocognitive effects of neurofeedback in children with ADHD. Eur Child Adolesc Psychiatry. 2018;27(5):581-93. http:// doi.org/10.1007/s00787-017-1072-1 PMid:29098467

30. El-Nagger NS, Abo-Elmagd MH, Ahmed HI. Effect of applying play therapy on children with attention deficit hyperactivity disorder. J Nurs Educ Pract. 2017;7(5):104.

31. Taylor SS, Abernathy TV. Behavior intervention flow chart: A strategic tool for managing challenging behaviors. Creat Educ. 2016;7(16):2423-32.

32. Stevens LJ, Kuczek T, Burgess JR, Hurt E, Arnold LE. Dietary sensitivities and ADHD symptoms: Thirty-five years of research. Clin Pediatr (Phila). 2011;50(4):279-93. http://doi. org/10.1177/0009922810384728 PMid:21127082

33. Fehr KK, Russ SW, levers-Landis CE. Treatment of Sleep problems in young children: A case series report of a cognitivebehavioral play intervention. Clin Pract Pediatr Psychol. 2016;4(3):306-17.

34. Kaduson HG, Schaefer CE. Short-term Play Therapy for Children; 2000

35. Bussalb A, Congedo M, Barthélemy Q, Ojeda D, Acquaviva E, Delorme $\mathrm{R}$, et al. Clinical and experimental factors influencing the efficacy of neurofeedback in ADHD: A meta-analysis. Front Psychiatry. 2019;10:35. http://doi.org/10.3389/fpsyt.2019.00035 PMid:30833909

36. Ioannides AA. Neurofeedback and the neural representation of 
self: Lessons from awake state and sleep. Front Hum Neurosci. 2018;12:142. http://doi.org/10.3389/fnhum.2018.00142

PMid:29755332

37. Beck R, Laugharne J, Laugharn R, Woldman W, McLean B, Thapa S, et al. APJNT Journal Table of Contents Title Authors Page\# 1 Modulating Cortical Asymmetry: The Trans diagnostic Reduction of Depressive and Anxiety Symptoms Utilizing a Novel Therapeutic Approach; 2019.

38. Schütze MD, Junghanns $K$. The difficulty of staying awake during alpha/thetaneurofeedback training. Appl Psychophysiol Biofeedback. 2015;40(2):85-94. http://doi.org/10.1007/s10484-015-9278-9 PMid:25835580

39. Jastrzębska E, Wadas E, Daszkiewicz T, Pietrzak-Fiećko R. Nutritional value and health-promoting properties of mare's milk a review. Czech J Anim Sci. 2017;62(12):511-8.

40. Dai $Y$, Liu J. Omega-3 long-chain polyunsaturated fatty acid and sleep: A systematic review and meta-analysis of randomized controlled trials and longitudinal studies. Nutr Rev. 2021;79(8):847-68. http://doi.org/10.1093/nutrit/nuaa103 PMid:33382879

41. Cohen S, Harvey DJ, Shields RH, Shields GS, Rashedi RN, Tancredi DJ, et al. The effects of yoga on attention, impulsivity and hyperactivity in pre-school age children with ADHD symptoms. J Dev Behav Pediatr. 2019;39(3):200-9. http://doi. org/10.1097/DBP.0000000000000552

PMid:29538185

42. Clark D, Seymour KE, Findling RL, Mostofsky SH. Subtle motor signs as a biomarker for mindful movement intervention in children with attention-deficit/hyperactivity disorder. J Dev Behav Pediatr. 2020;41(5):349-58. http://doi.org/10.1097/ DBP. 0000000000000795

PMid:32555070

43. Dolezal BA, Neufeld EV, Boland DM, Martin JL, Cooper CB. Interrelationship between sleep and exercise: A systematic review. Adv Prev Med. 2017:2017:1364387. http://doi. org/10.1155/2017/1364387

PMid:28458924

44. Wang F, Boros $S$. The effect of physical activity on sleep quality: A systematic review. Eur J Physiother. 2021;23(1):11-8.

45. Mason R. $200 \mathrm{mg}$ of Zen: L-Theanine boosts alpha waves, promotes alert relaxation. Tohoku J Exp Med. 2001;7:91-6.

46. Kim S, Jo K, Hong KB, Han SH, Suh HJ. GABA and I-theanine mixture decreases sleep latency and improves NREM sleep Pharm Biol. 2019;57(1):65-73. https://doi.org/10.1080/1388020 9.2018.1557698

PMid:30707852 